\title{
Treating primary headaches - management of migraine
}

\author{
Dimos D Mitsikostas \\ From The European Headache and Migraine Trust International Congress \\ London, UK. 20-23 September 2012
}

\begin{abstract}
Migraine is a common chronic neuronal disorder with episodic attacks affecting the one tenth of the general population with enormous social impact. The management of the disorder includes several approaches, both behavioral and pharmaceutical interventions, preventive or symptomatic ones. Exceptionally, invasive treatments may be required as well. A plentiful pallet of pharmacological agents covers symptomatic treatment, further divided into specific and nonspecific anti-migraine agents. Apart from triptans, ergot alkaloids are also included in the specific anti-migraine drugs. Triptans, share a common pharmacological profile targeting to $5-\mathrm{HT} 1 \mathrm{~B} / 1 \mathrm{D} / 1 \mathrm{~F}$ receptors with different pharmacokinetic and pharmacodynamic properties resulting to slight diverse efficacy and safety that may be important for the treatment goals. Triptans are recommended as initial treatment for moderate to severe migraine attacks, or when other agents failed to reach the expected therapeutic benefit in less-disabled patients. For migraine prophylaxis valproate, topiramate and flunarizine are recommended. In the case of chronic migraine, a disabling subform of migraine, with or without medication overuse, onabotulinumtoxin A and topiramate are suggested. A variety of behavioral treatments are available for those patients they experience increased stress in particular. Although numerous, the above treatments may not be enough to manage migraine appropriately even in the right hands, rising needs for future treatments with improved efficacy and safety profile. CGRP antagonists and specific 5-HT1F agonists are potential future symptomatic agents for migraine.
\end{abstract}

doi:10.1186/1129-2377-14-S1-01

Cite this article as: Mitsikostas: Treating primary headaches management of migraine. The Journal of Headache and Pain 2013 14(Suppl 1):01

Neurology Department, Athens Naval Hospital, Greece
Submit your manuscript to a SpringerOpen ${ }^{\bullet}$ journal and benefit from:

- Convenient online submission

- Rigorous peer review

- Immediate publication on acceptance

- Open access: articles freely available online

- High visibility within the field

- Retaining the copyright to your article

Submit your next manuscript at $\gg$ springeropen.com

\section{SpringerOpen ${ }^{\circ}$}

(C) 2013 Mitsikostas; licensee Springer. This is an Open Access article distributed under the terms of the Creative Commons Attribution License (http://creativecommons.org/licenses/by/2.0), which permits unrestricted use, distribution, and reproduction in any medium, provided the original work is properly cited. 